\title{
Towards Transitional Justice? Black Reparations and the End of Mass Incarceration
}

\author{
Desmond King (Oxford) and Jennifer Page (Zurich)
}

Domestic reparations movements - which consist of citizens pressuring their own governments for acknowledgment, accountability, and symbolic and material redress - share many common aims with transitional justice. As with domestic reparations movements, transitional justice seeks to directly address past abuses, and rails against the tendency in politics to ‘forget and move on’ (Crocker 1998: 495). Neither transitional justice practitioners nor domestic reparations activists tend to see standalone apologies as enough; concrete actions must be taken to demonstrate accountability for the past.

It is perhaps surprising that, in spite of overlaps such as these, domestic reparations movements have not made greater use of the concept of transitional justice in framing their case for acknowledgment and redress. In this article, we look at the movement for reparations for enslavement and Jim Crow in the United States - sometimes called the 'black reparations movement’ (Darby 2010) - as an example of a domestic reparations movement that could reasonably frame its case in terms of transitional justice. ${ }^{1}$

There is rhetorical and moral power in using the language of transitional justice in the context of the United States, since this invites comparison between the US and other 'emerging' democracies. It implicitly challenges the longstanding tendency to think of the US as an 'established' democracy - indeed, as one of the oldest in the world. But the main point of our essay is not this. It is rather to point out affinities between the goals of transitional justice and the

\footnotetext{
${ }^{1}$ In keeping with the editorial policies of Ethnic and Racial Studies, we use lower-case initial letters for 'black/blacks' and 'white/whites'. The argument of this paper does not hinge on a distinction between the designations 'black’ and 'African American'; accordingly, we use both terms.
} 
goals of the black reparations movement, and to discuss how a future transitional moment - the end of mass incarceration - could open up new paths to redress.

The argument proceeds as follows. In section one, we discuss the theory of transitional justice and how it can be understood as applicable to continuous political regimes. In section two, we discuss the black reparations movement in the United States. Section three draws a contrast between remedial and transitional justice. Finally, section four considers the end of mass incarceration as a future transitional moment that could spur the payment of reparations and a formal investigation into America’s legacy of racial injustice.

\section{Contextualizing transitional justice}

First used in 1991, the terminology of ‘transitional justice’ was proposed by Ruti Teitel as a way of thinking about then-recent transitions to democracy in Latin America and the dissolution of the Soviet Union. Teitel's aim was, in her own words, to 'account for the selfconscious construction of a distinctive conception of justice associated with periods of radical political change following past oppressive rule' (Teitel 2014: 3). Transitional justice was conceived in order to think through a unique set of practical challenges faced by post-conflict societies: How to deal with those who carried out atrocities on behalf of the previous regime? Punishment or impunity? What about colluders? What is owed to the victims?

Instruments typically associated with transitional justice include truth commissions, reparations, and criminal prosecutions. As Jon Elster (2004) argues, though the language of transitional justice is recent, its particular challenges and methods are ancient, going back to the early days of Athenian democracy. It is thus not anachronistic to think about what transitional justice may have required before the late $20^{\text {th }}$ century, or to think about measures undertaken in any time of political upheaval as having implicit transitional justice aims. 
Times of political upheaval and formal regime change are not necessarily the same, however. On one view of transitional justice, it is reserved for the most extraordinary of domestic political events: when an oppressive government is toppled through war or revolution, and a new democratic regime claims the right to rule. Understood thusly, transitional justice is a time-limited set of practices designed to close the books on the previous political era (see Williams and Nagy 2012: 20-21 for a discussion). Yet the question arises, is transitional justice relevant to continuous domestic political constitutions? Is it a formal regime change that triggers transitional justice measures, or is it the presence of atrocities?

These questions came up recently when the United States Department of State issued a white paper advocating truth commissions and other forms of transitional justice for societies with legacies of 'large-scale and often systematic atrocities' (US Department of State 2016). A New York Times journalist, Anand Giridharadas, contacted the State Department to see whether the white paper was intended to apply to the domestic United States, particularly with regard to its legacy of enslavement and segregation. The spokesperson's initial reply was evasive, and to Giridharadas's specific question as to whether 'the United States in fact fits the description of a country transitioning out of conflict', the State Department responded: 'I won’t have anything further for you' (Giridharadas 2016).

The case for thinking of the United States as a country that has leveraged large-scale and systematic atrocities on its black population - and therefore as a country to which transitional justice is relevant - is laid out by Andrew Valls (2003). As Valls argues, there have been at least two periods in US history that fit our standard understanding of democratic regime transitions. The first occurred during the Reconstruction period, following upon the upheaval of the Civil War and the transition from the atrocities of chattel slavery to the democratizing Thirteenth and 
Fourteenth Amendments (Valls 2003; see also Teitel 2002: 152-157). The second transition took place during the Civil Rights era. Marked by the passage of the Civil Rights Act (1964) and the Voting Rights Act (1965), this transition saw the end of Jim Crow and the abuses inherent in

'Black Codes', enforced by the lynch mob. As Valls writes:

In both cases the state... enforced racial subordination and permitted private citizens to violate the human rights of members of the subordinated class with impunity. In both cases, equal protection of the law and equal political representation were denied. In both cases, the state and society at large then underwent a transformation in which governmental policy shifted to no longer practicing the systematic violation of basic human rights of its racially subordinated populations.... (Valls 2003: 61).

Valls argues that without satisfying minimum levels of transitional justice, democratic transitions can remain incomplete. During the US's two major transitions, the basic mechanisms of transitional justice - prosecuting individuals who committed atrocities, setting the historical record straight about the abuses that occurred, and paying redress to the victims - were neglected.

Since the Reconstruction period, African Americans have pushed for the United States government to pay reparations for enslavement and segregation. The language of transitional justice has never been explicitly employed as central to the black reparations movement, though this movement was active in the 1990s and beyond. Yet the idea of incomplete transitional justice has untapped potential in making the case for reparations. Let us turn to the black reparations movement.

\section{Black reparations in the United States: judicial vs. legislative strategies}

In the United States, reparations activists have made use of both judicial and legislative strategies in pushing for redress for freedmen and women, and later on for the descendants of the 
enslaved. In this section, we provide a brief overview of the activities of the multi-generation black reparations movement through the lens of these two strategies.

\subsection{The judicial route}

How African Americans have used the courts to challenge unjust laws and political formations is well-known. Less familiar is the use of the courts as a means of seeking redress for state-sponsored injustice. During Reconstruction and beyond, groups of freedpersons pressured the government to provide monetary relief to the formerly enslaved. The most prominent of these groups, the National Ex-Slave Mutual Relief, Bounty, and Pension Association, employed the clever tactic of suing the government for the amount that it had collected in taxes on cotton. Johnson v. McAdoo was heard by the Supreme Court in 1917, but in a short opinion, the majority justices affirmed the lower court's ruling that sovereign immunity - i.e., the common law principle that a political subject cannot sue the government without the latter's consent - barred the case (Berry 2005).

In more recent times, members of a group called the National Coalition of Blacks for Reparations in America (N’COBRA), founded in 1988 by Imari Obadele and Adjoa Aiyetoro, have pursued reparations in the courts (Berry 2005: 244). The 1995 case Cato v. United States sought reparations to slave descendants for the 'forced, ancestral indoctrination into a foreign society; kidnapping of ancestors from Africa; forced labor; breakup of families; removal of traditional values; deprivations of freedom; and imposition of oppression, intimidation, miseducation and lack of information about various aspects of their indigenous character', as well as an official apology. In litigated reparations cases, an expired statute of limitations is often an insurmountable barrier, but the Cato plaintiffs argued that no statute of limitations should

apply based on the continuing violations doctrine: 'African Americans are still subjected to the 
badges and indicia of slavery'. The 9th Circuit justices did not dispute this claim per se, but found that sovereign immunity barred the case, as it had for its 1917 predecessor (Aiyetoro 2004).

The plaintiffs' argument that they faced a continuous violation of their rights created a new obstacle: the standing doctrine (Aiyetoro 2004). According to the standing doctrine, the basis for challenging the government must be that the repeated enforcement of an unconstitutional law would bring about a foreseeable future injury to the plaintiff. This means a current law or government practice must be causally linked to a particular injury which the plaintiff herself is in danger of experiencing; standing prevents a plaintiff from pursuing relief for others without their knowledge. The court found that Cato was unable to surmount this requirement: 'Cato proceeds on a generalized, class-based grievance’, and did not name a 'concrete, personal injury that is not abstract and that is fairly traceable to the government conduct that she challenges as unconstitutional'. This not only applied to the claim for monetary redress, but also to Cato’s seeking an apology, ruled the court.

In addition to Cato, N'COBRA affiliates have pursued redress against companies that used slave labour, illegally sold insurance policies on the lives of the enslaved, and accepted the latter as collateral on loans. The opinions in these cases underscore the mismatch between the motivating ambitions of the lawsuits and the narrow legal standards used by courts. 'There is no way to determine that a given black American today is worse off by a specific, calculable sum of money (or monetized emotional harm) as a result of the conduct of one or more of the defendants', ruled the court in the consolidated case In re African American Slave Descendants Litigation (2006). It went on to equate the case to a hypothetical one in which a descendant of a fallen Union soldier sues present-day gun manufacturers whose historical predecessors illegally 
sold munitions to the Confederacy.

In spite of outcomes like this, it makes sense why claimants would have wanted to pursue reparations judicially. Pessimism that white public opinion would ever favour Congressional legislation for reparations is understandable, and rolling the dice for an activist liberal judge would seem to be a better bet. But it is nevertheless a time-honoured lawyerly custom to try and bypass the unruly masses, whose indoctrinated ideologies and self-serving beliefs impede progress, in order to secure social change through the courts (Unger 1996). Indeed, Adjoa Aiyetoro, one of the N'COBRA co-founders, and Deadria Farmer-Paellmann, organizer and lead plaintiff in the corporate redress lawsuits, are law professors.

There are parallels between post-Civil Rights era workplace affirmative action and school desegregation efforts, and the strategy of pursuing reparations through the courts. Both affirmative action and school desegregation were remedial social policies based in judicial mandates, rather than in legislation. Affirmative action began as an administrative invention, and expanded under the oversight of judges in its heyday (King and Smith 2011, Skrentny 1996). It is significant that debate over affirmative action was heated, and white opposition strong, with critics charging 'reverse racism'. School desegregation, like affirmative action, came from above, for the most part mandated by federal courts. Again, there was significant opposition. White students resisted integration by harassing black newcomers with racist slurs and forms of physical violence (e.g., Beals 1994, Ch. 7), and parents were quick to move their children to new school districts or enrol them in private school (Clotfelter 2004).

Given the high stakes, the course of action taken by the courts - 'legislating from the bench’ though it may have been - was reasonable (cf. Brooks 1996: 104-108). At issue was the second-class citizenship of African Americans, and if the government had waited for a strong 
contingency of whites to favour race-conscious remedial policies, the danger was that whites would never come around. Yet a bill up for debate in Congress would have provided an opportunity for anti-affirmative action and anti-integration whites to publicly air their positions. ${ }^{2}$ When public debate emerges in anticipation of a major legislative decision, rather than as a response to a judicial ruling that has been handed down, the outcome is more likely to be seen and accepted as legitimate by those who disagree with it (Waldron 2006).

The position that decisions of great moral importance should be determined by the legislature is known as the 'political question doctrine', a common subject in American debates over judicial review. The appellate justices invoked the political question doctrine explicitly in In re African American Slave Descendants Litigation, citing prior cases which 'simply exceeded judicial capabilities’.

\subsection{The legislative route}

The driving force behind contemporary slavery reparations lawsuits has been a fundamental concern with justice, regardless of white acceptance of the cause (Ogletree 2004: 14). But it would be a missed opportunity if reparations were paid, and afterwards there were no differences in racial power relations. In this regard, legislative redress - the other major strategy pursued by the black reparations movement - has natural potential. H.R. 40 is a bill that Representative John Conyers, who is black, has introduced every Congressional session since 1989, proposing to set up a committee to study proposals for reparations. ${ }^{3}$ Its title a reference to the failed post-Civil War promise of 'forty acres and a mule' to freedpersons, the bill has never been taken seriously enough to make it out of committee. As Representative Conyers

\footnotetext{
${ }^{2}$ Note that numerous congressional hearings did permit critics to vent their spleen against these policies and to blame the Labor Department for affirmative action schemes likes the Philadelphia Plan (Skrentny 1996).

${ }^{3}$ N.B. In 1989, the bill was called H.R. 3745.
} 
emphasizes, the bill is moderate in that it is fundamentally a study bill: 'We study the water, the air. We can't even study the issue? This bill does not authorize one red cent to anyone' (Coates 2014).

Compared to a court-ordered reparations payment, legislative redress has a better chance of being seen as the outcome of a debate over which the American public has some, if not total, ownership (Westley 1998). Of course, it is not likely that this debate would be wholly salutary. Japanese Americans were successful in obtaining internment reparations through Congress (after a failed attempt in the courts) in spite of having inspired the formation of anti-redress organizations like ‘Americans for Historical Accuracy’ (Henry 2003). A recent poll has shown a spike in support among millennials for black reparations (Holland 2016), and this piece of information alone has triggered scorn from the right. 'Young people are spoon-fed garbage from academia and the media that somehow blacks are under the boot of a racially biased system, an idea that is totally anti-intellectual', as one web commentator wrote (Girdusky 2016). If H.R. 40’s passage were imminent, we might expect a flurry of pointed opposition, and even increases in activity among white supremacist groups, confederate flag displays, and hate incidents. At the same time, backlash is expected given the bill's overall message - indeed, it bears out the urgency of the message - viz., a historical legacy that includes enslavement and Jim Crow is still with us today.

The black reparations movement is not monolithic, but support for H.R. 40 is wideranging. N'COBRA backs H.R. 40, as does the NAACP, which 'strongly supports' the bill (McCoy 2014). ${ }^{4}$ In addition, there have been forays into a deliberate campaign to build greater support for the proposal, combining the efforts of individual groups dedicated to the cause of

\footnotetext{
4 The United Nations' Working Group of Experts on People of African Descent also endorses H.R. 40 ('Report' 2016: 20).
} 
black reparations and other pro-reparations community organizations. N'COBRA has held numerous reparations events; Chicago Alderman Dorothy Tillman hosted multiple conferences on the topic; and a 2004 National Reparations Congress in Compton, California drew representatives from 50 organizations. Yet these efforts have not resulted in the broad mainstream support, even among blacks, that Clarence Munford once conceived of as necessary - albeit before the dawn of the present Black Lives Matter movement:

Reparations slogans and buzzwords must become household words across black America. We must put our issues and topics on every African American lip. Thereby we may hope to regenerate the mass black liberation movement that has languished in suspended animation since the 1970s (Munford 2007: 447). ${ }^{5}$

In this vein, Manning Marable (2004: 4) considers 'convincing black people, not whites, that we can actually win' to be 'the greatest challenge' of black reparations. Perhaps this is overstated. In spite of the uptick in millennial support, whites are staunchly opposed to reparations. A 2004 study found that 96 percent of whites were against black reparations (Dawson and Popoff 2004). The same 2016 poll that broke down support for reparations by age found that 81 percent of whites were opposed to reparations - an improvement, but far from majority support. Munford, however, did not think that majority white support was needed to create the political pressure to pass a reparations bill. 'A coalition between a black America united for reparations and an antiracist white minority rallying in support of black reparations can prevail over mass white opposition', he argued (Munford 2007: 451).

At the present moment, of course, much of the mobilization around racial injustice has centred on police violence and overly harsh penal policies. However, a transitional moment in this policy arena could provide a window of opportunity for the reparations movement. If the 'New Jim Crow' system of mass incarceration was dismantled, and sweeping reforms passed in

\footnotetext{
${ }^{5}$ See also Howard-Hassmann 2004.
} 
the areas of law enforcement and criminal justice, black reparations advocates and activists could make the case that the racial history of the post-Civil Rights era incarceration policy, a racialized war on drugs, and so on, are the contemporary manifestations of anti-blackness in America, and that tangible reparations are owed. Indeed, the groundwork for this is already laid out in the contemporary Black Lives Matter movement: One of the six pillars of the umbrella group 'The Movement For Black Lives’ is reparations ('Platform’2017).

A renewed push for reparations in the United States, as we argue, would mostly likely be successful in a transitional moment, and would moreover benefit from the language and moral logic of transitional justice. Before making this argument in full, it is necessary to turn to an allimportant distinction between transitional justice and remedial justice.

\section{Transitional vs. remedial justice}

The scale of black-white inequality in the United States is daunting (King 2014). Instead of the wealth gap diminishing over time, it is becoming more substantial: results based on analysis of the Panel Survey of Income Dynamics show that in the 23 years prior to 2007, the wealth gap between African American and white households increased by \$75,000, from $\$ 20,000$ to $\$ 95,000$ (Shapiro et al 2010). Durable inequalities are also present in income, not just wealth. Considering the per capita income differential between white and African American workers in 1968, john powell (2007: 42) calculates that at the present pace of change, 'it would take blacks 580 years' to close the gap. A Federal Reserve study moreover finds that African Americans are much less the beneficiaries of upward income mobility, and more likely to move downward than whites. Using two sets of intergenerational data, Mazumder (2014: 8) finds that 'more than 50 per cent of blacks who start in the bottom quintile in the parent generation remain there in the child generation, but only 26 per cent of whites remain in the bottom quintile in both 
generations'.

Statistics like these suggest these seem to bolster the claim that African Americans are owed reparations for intergenerationally-transmitted inequalities that show no sign of abating on their own. The point of reparations, so it seems, would be to overcome economic inequalities tracking racial lines.

Here a distinction between what is sometimes called corrective or remedial justice and transitional justice is relevant. Remedial justice consists of policies and programs designed to remedy the harmful effects of past injustice. Transitional justice, by contrast, is more focused on the causes that gave rise to the harmful effects, particularly rights violations, abuses, and atrocities. Because of its focus on causes, transitional justice is more interested in identifying perpetrators (even if amnesty is ultimately preferred to retribution), whereas remedial justice repairs harms without necessarily placing blame. This is not to say that transitional justice is only concerned with blame and unconcerned with repairing harms. But, for the transitional justice practitioner, coming to terms with past abuses and repairing harms go hand-in-hand.

The methods of transitional justice and remedial justice can and do overlap: monetary redress, land restitution, and programs designed to correct particular inequalities are associated with both. However, the spirit in which such measures are undertaken varies significantly depending on whether a transitional or remedial justice standpoint is adopted. Consider affirmative action in the United States. Though affirmative action emerged during a transitional moment, on the heels of the Civil Rights movement, it was quintessentially a remedial justice program. As Owen Fiss, a Yale law professor and prominent white affirmative action advocate, describes the dilemmas that the policy fell into:

For rejected white applicants, there is the frustration of desire, of not being able to attend particular schools or to obtain specific jobs. In addition, these applicants 
suffer a hurt that blacks know all too well - the hurt that comes from being judged disfavorably on a criterion unrelated to individual merit and over which they have no control. These grievances are indeed genuine; they are wrongs never to be forgotten and never to be trivialized... In an imperfect world, a great transformation cannot be achieved without pain and sacrifice, without even a measure of injustice. Surely, this must be the great lesson of the Civil War (1997: 38).

Remarkably, Fiss is claiming that a white student with test scores equivalent or higher than her successful black counterpart who winds up at a lower-ranked university experiences a wrong 'never to be forgotten and never to be trivialized'. He calls attention to her 'pain', her 'sacrifice', the 'injustice' - a sort of noble martyrdom which apparently warrants comparison to the Civil War's Union soldiers. But this formulation dangerously undervalues the sacrifices of those born into racial domination. Ironically, Fiss seems to be in the peculiar position of advocating that we forget these sacrifices - he explicitly rejects that affirmative action should have a backwardlooking justification - while wanting us to never forget the sacrifices made by whites so that blacks may be equal.

Understood thusly, there is little difference between remedial justice, aiming to repair harm without tracing harm's origin or placing blame, and distributive justice, which determines how to allocate goods fairly. Whether African Americans are given a 'racial preference' in hiring and university admissions because of the harm of being disproportionately underrepresented or because of the unfair allocation implied in their disproportionate representation, the end result is the same. Efforts are made to increase their numbers without reference to past injustices as the reason for the disparity. Here an observation made by Derrick Bell (1979: 8) rings true: the very language in which debates on the matter are conducted - affirmative action, preferential treatment - 'sounds in noblesse oblige', suggesting 'the giving of charity rather than the granting of relief'. 
We hypothesize - though without fully exploring the claim here - that during the major transitional moments in United States history, programs undertaken to advance the material and social equality of black Americans have been enacted under the banners of remedial and distributive justice, with little to no attention paid to racial inequality's origins. In addition to affirmative action, such programs include school desegregation and, in the postbellum period, the Freedmen's Bureau. ${ }^{6}$

By contrast, advocates of black reparations have always been intensely focused on enslavement and segregation as the sources of intergenerationally-transmitted harms, and on coming to terms with America’s past as essential to any program of monetary redress. Certainly this is the whole point of Representative Conyer's H.R. 40 proposal. Yet our worry is that, in spite of the injustice of slavery and Jim Crow's centrality to the black reparations movement, this is easily glossed over by a remedial mentality that arises in reflecting on black-white material inequalities.

Consider the publication of Ta-Nehisi Coates’s 15,000-word essay, 'The Case for Reparations' in the June 2014 issue of the Atlantic - an event which, if briefly, triggered widespread public debate about the ‘compounding moral debts’ owed to black Americans. Debunking the myth of American innocence, and calling for a full examination of the abuses wrought by enslavement and segregation, were Coates’s chief aims. But Coates also devoted a portion of the essay to examining West Germany’s payment of monetary reparations to Israel following the Holocaust. Reparations, in other words, could not just take the form of collective soul-searching. The debt would have to be paid off.

\footnotetext{
${ }^{6}$ It is true that symbolic reparative measures have been undertaken at various point, such as designating February 'Black History Month' and issuing Congressional apologies for slavery and lynching. But these have not been part of a broader program to interrogate the past as a means of trying to repair the past.
} 
Coates's essay inspired many responses, with some commentators arguing that the proposal of material reparations was not so unrealistic. Slate journalist Jamelle Bouie contrasted direct cash payments to a more palatable 'policy approach’:

Instead of cash, the federal government would implement an agenda to tackle racial inequality at its roots. This agenda would focus on major areas of concern: housing, criminal justice, education, and income inequality. As for the policies themselves, they don't require a ton of imagination. To break the ghettos and reduce the hyper-segregation of black life, the federal government would aggressively enforce the Fair Housing Act, with attacks on housing and lending discrimination, and punishment for communities that exclude low-income residents with exclusionary zoning (Bouie 2014).

Bouie's response went on to discuss improving education and criminal justice reform as other important aspects of 'policy reparations'.

Bouie makes clear that he shares Coates' belief in the importance of undertaking a critical examination of the racist foundations of the American republic. But one can easily imagine a program of 'policy reparations' being implemented in a way that is completely ahistorical, for remedial and distributive justice reasons.

A deliberate program of transitional justice, however, eschews the methods of ahistorical remedial justice. The difference between transitional justice's focus on rights violations and abuses (that may give rise to unjust inequalities) and remedial justice's focus on unjust inequalities (that may be caused by rights violations and abuses) is important. A form of transitional justice that fails to attend to past wrongdoing can criticized as not properly being transitional justice.

To be clear, our aim here is not to make a normative argument about why the methods of transitional justice might be preferable to remedial justice, or why past injustices should be confronted. Again, it is to show that there is common ground between the aims of domestic reparations movements and transitional justice, and to argue for the usefulness of transitional 
justice to the domestic movements. Suffice it to say, looking at the way the black reparations movement frames its goals - e.g., 'to heal the wounds of centuries of disdainful, brutal and inhumane treatment that the international community acknowledges as a crime against humanity' (Aiyetoro 2001: 474) - it seems clear that at issue is unjust causes and harmful effects, and not just the latter on their own. As such, the movement has a greater affinity with transitional than with remedial justice.

Moreover, given the general complacency of many Americans, especially white Americans, regarding durable material inequalities between blacks and whites, it may only be during a 'transitional' political moment that the claim to reparations has a chance of success. The end of mass incarceration holds promise to be such a transitional moment.

\section{The end of mass incarceration: a time for reparations?}

The United States has the highest incarceration rate worldwide (Alexander 2012, Travis et al. 2014). This was not always the case. During the 1950s, the US’s incarceration rate was comparable to other advanced industrial nations. Carceral expansion originated in the crime policies of the 1960s, and proliferated dramatically in the 1970s. These days, Americans are incarcerated at a rate five to ten times higher than their counterparts in other advanced industrial nations (Travis et al. 2014). ${ }^{7}$

The significance of carceral expansion's origins in the 1960s is deeply tied to race. As Vesla Weaver (2007) argues, increasingly punitive crime policy originated as a proactive response by white elites to the gains of the Civil Rights movement. 'Mass imprisonment', a term first defined by sociologist David Garland, is a trait of criminal justice systems wherein 'it ceases to be the incarceration of individual offenders and becomes the systematic imprisonment of

\footnotetext{
${ }^{7}$ This is in spite of there being similar levels of crime in the United States and other advanced industrial nations.
} 
whole groups of the population' (Garland 2001: 2). Michelle Alexander (2012: 6) points out that the percentage of the black population behind bars is higher in the contemporary United States than in South Africa during apartheid. Young black men are incarcerated at such high rates that sociologists have come to consider prison a stage in the 'life course’ (Pettit and Western 2004). At any given point in time, 44 percent of black women and 32 percent of black men have a family member in prison (Lee et al. 2015).

In recent years, the US's approach to incarceration has been viewed with increasing critical scrutiny. In fact, ending mass incarceration is an issue that has received bipartisan political support. The non-partisan Brennan Center for Justice recently published a book featuring essays from prominent Democrats and Republicans all arguing for the imperative of criminal justice reform (Chettiar and Waldman 2015). It is not inconceivable that Congress could pass sweeping criminal justice reforms that, in effect, would dismantle mass incarceration. ${ }^{8}$

If this were to happen, one thing is almost certain: the end of mass incarceration would not be an ex gratia act by political elites. Already the contemporary Black Lives Matter movement has brought much greater visibility to mass incarceration (Harris 2015), and draws comparisons with previous generations of Civil Rights activists (Porter 2016). If legislation is passed that is to mass incarceration what the Civil Rights Act of 1964 was to racial discrimination, this would likely be the result of dedicated, sustained grassroots pressure.

In light of this, recall the point that Black Lives Matter activists have embraced the earlier work of the black reparations movement, incorporating reparations into their formal platform. The end of mass incarceration would bear a significance that could justify a renewed push for

\footnotetext{
${ }^{8}$ Because it is not the focus of this essay, we do not go into detail about what policies the end of mass incarceration would consist of. But naturally, this is a topic that others have written about (see, e.g., Austin and Eisen 2016). N.B., it is also possible that mass incarceration will be dismantled incrementally, a scenario that would not seem as conductive to our vision of a national program of transitional justice.
} 
reparations. In the black radical tradition, the racial epochs of American history are often understood as a chronology of enslavement, segregation, and mass incarceration (Davis 2016), with each recalling the ghosts of previous epochs. The title of Michelle Alexander's bestseller on mass incarceration, 'The New Jim Crow', references this ‘historical sequence of "peculiar institutions"' (Wacquant 2001: 95). The end of the first two epochs saw remedial policies - the Freedmen's Bureau following the end of slavery, school desegregation and affirmative action following the end of segregation - but not transitional justice. The end of mass incarceration, signifying a major democratic transition, presents an opportunity to do better.

We envision a national program of transitional justice inaugurated by Congressional legislation, either H.R. 40 or a successor bill. Like the injustices at issue in many post-conflict contexts, mass incarceration is a multifaceted, multi-layered state-sponsored injustice enabled by widespread societal participation. The federal government is a responsible party for its part in mass incarceration, but also plays the role of a moral 'respondeat superior' (1) as the highest level of government in a highly complex system in which past and present actors at the state, county, and municipal levels are complicit parties; and (2) insofar as it represents ordinary citizens whose attitudes towards and actions around crime and punishment have contributed to a political climate enabling mass incarceration. ${ }^{9}$ Accordingly, the federal government should oversee a program of transitional justice, unequivocally taking responsibility for contributions to mass incarceration at the federal level. But, it should also encourage lower-level governments,

\footnotetext{
${ }^{9}$ See Page 2015 for more on the 'moral "respondeat superior"'. How responsibility for mass incarceration should be understood is an issue much larger than the present analysis can satisfactorily discuss, but to be clear, on our understanding, it is not necessary to think that that there was a grand blueprint for mass incarceration that individual actors carried out. Mass incarceration, in our view, developed more organically, at multiple sites and in response to multiple factors. On normative accounts of responsibility (e.g., Pettit 2007), state actors and institutions can reasonably be understood as contributing to the state authorization of injustice, while leaving room for the causal role played by broader social structures and public attitudes.
} 
government officials, and members of society to reflect on and take responsibility for their actions and attitudes, and to join in as co-participants in the transitional justice process.

In the remainder of this section, we discuss different dimensions of transitional justice, and how they could be adapted to the context of mass incarceration in the United States.

\subsection{Creating a public record}

In most democratic transitions, the need arises to create an institutionalized public record that is able to counter revisionist claims and to show that public officials are committed to understanding and accepting the truth of past abuses, regardless of how damaging to a country's self-understanding or reputation. The end of mass incarceration would be no exception. Public hearings could be set up nationwide to collect testimony from individuals unjustly incarcerated due to draconian 'three strikes' laws and mandatory minimum sentences; ${ }^{10}$ who were subject to lengthy pre-trial detentions because they could not afford bail; ${ }^{11}$ who pled guilty to spurious charges to escape pre-trial detention, ${ }^{12}$ or because subject to 'third degree' practices or other harsh interrogation tactics; ${ }^{13}$ and so on. Testimony could also be collected from family and community members of the incarcerated, as well as from prison guards, police officers, lawyers, judges, and ordinary citizens. Because carceral expansion has affected persons of all races, testimony on the 'victim' side would not be limited to African Americans. However, one of the central goals of the hearings could be to collect testimonies that specifically speak to the theme of black humanity - in keeping with the spirit of the Black Lives Matter movement (Harris 2015)

\footnotetext{
${ }^{10}$ See Alexander 2012.

${ }^{11}$ See Subramanian et al. 2015.

12 Discussed in Heaton, Mayson, and Stevenson 2017.

13 See Skolnick and Fyfe 1994, Ch. 3.
} 
- and that contextualize mass incarceration as part of a historical legacy that includes enslavement and segregation.

Would these public hearings be understood as part of a 'truth commission'? A 'truth and reconciliation' commission? The form is important. However, it also should be a matter of public debate and ownership. If Americans were to self-consciously embark upon a national project of transitional justice in the wake of mass incarceration, they would have look to other countries for examples of each approach, and decide which model or models to emulate. ${ }^{14}$

\subsection{Reparations}

Boris Bittker’s 1973 work The Case for Black Reparations was the first book on black reparations hailing from the legal academy. Bittker's proposal was to pay monetary redress to individual African Americans who attended segregated schools (Bittker 1973). A long debate has ensued about whether reparations should in fact be paid to individuals, or should go to African Americans as a group - a 'Reparations Superfund' administered by black trustees (Berry 2014).

A future national project of transitional justice should include a reparations component. In the spirit of Bittker's post-Civil Rights era proposal, reparations could be paid to formerly incarcerated people. Alternatively, a Reparations Superfund could be used to fund projects in disadvantaged black neighbourhoods that mass incarceration has hit the hardest. There have also been other reparations proposals, like the idea of 'Baby Bonds' (Hamilton and Darity 2010). We do not take a stand in favour of a particular proposal, but stress that it is not only the general public's input that should be sought. Nuti and Amighetti (2015) have argued that, in deciding what form reparations should take, government officials should bring in stakeholders for a

\footnotetext{
${ }^{14}$ Ifill (2003) proposes a truth and reconciliation commission for lynching, going into much more detail than we do here. Davis (2016) discusses restorative justice as a basis for a truth and reconciliation commission for violence against African Americans.
} 
process of deliberation. A deliberative forum could be held bringing together African Americans from all over the country to give their input, or the public hearings could be used to collect testimony on the question of what kind of reparations are owed.

\subsection{Tailored measures}

A national program of transitional justice should also include ‘tailored measures’ (Page 2015). Though not usually formally considered as part of the transitional justice toolkit, this is in keeping with the arguments of transitional justice scholars who point out that transitional justice is localized in practice (Williams and Nagy 2012). There may be measures that serve transitional justice aims - helping victims heal, cultivating trust, creating paths to reconciliation, and so on that are only discernable by attending to the particular circumstances giving rise to a transitional justice response.

For instance, in Chicago in the 1970s and 1980s, police commander Jon Burge subjected over one hundred African American men to torture in order to extract confessions (Taylor 2015). The subsequent grassroots reparations campaign culminated in 2015, when the city of Chicago passed a reparations ordinance allocating an apology, a memorial, monetary redress, including police torture in Chicago public school curricula, free college education for the torture survivors and their kin, and a counseling center for the torture survivors. The latter two elements are the tailored measures, addressing the fact that the torture victims were imprisoned on illegally obtained, often false confessions. Like many formerly incarcerated people, the men tended to struggle with finding stable work upon reentry, and expressed interest in receiving educational support and access to a career center. Now up and running (Eltagouri 2017), the Chicago Torture Justice Center could serve as a prototype as a kind of tailored measure appropriate to transitional justice in the wake of mass incarceration. 


\subsection{Accountability}

A final category of transitional justice, 'accountability', creates difficulties in the context of transitional justice for mass incarceration. Many activists dedicated to ending mass incarceration are restorative justice activists; others identify as prison abolitionists. Transitional justice often involves criminal prosecution and punishment for government and military officials who committed atrocities, but this would hardly seem appropriate in the context under consideration. Alternative forms of accountability - perhaps restorative justice, perhaps other alternatives to incarceration that may emerge in the future - should be considered for those who have leveraged criminal justice-related abuses under colour of law.

\section{Conclusion}

In the past few years, there have been at least two hopeful moments for black reparations advocates and activists. The first was the publication of Ta-Nehisi Coates's 'The Case for Reparations' and the largely positive reception given to the essay. The second was a 2016 report issued by the United Nations' Working Group of Experts on People of African Descent. 'Despite substantial changes since the end of the enforcement of Jim Crow and the fight for civil rights', the report stated, 'a systemic ideology of racism ensuring the domination of one group over another continues to impact negatively on the civil, political, economic, social and cultural rights of African Americans today’ ('Report’ 2016: 4). Among the Working Group’s proposals were comprehensive reparations (Ibid.: 20). This received mention in many news outlets, though not inspiring nearly the same level of commentary as Coates's piece.

That a major American newsmagazine was willing to devote almost an entire edition to the topic, and that a group housed at the United Nations chose to spend time and political capital 
on the subject, suggests that reparations to African Americans are not a fringe idea. And yet, it seems hard to imagine a moment any time soon in which, as Clarence Munford envisioned, a united black majority and a strong contingent of antiracist whites and other people of colour would come together, rallying around reparations. As we have argued in this essay, there are strong affinities between the goals of transitional justice and domestic reparations movements. A major democratic transition, such as the end of mass incarceration no doubt represents, would provide an opening for the language and moral logic of transitional justice. This would be an opportunity not only to push for monetary redress, but also for a public inquiry into American racial history's most recent epoch and the ones preceding it.

\section{Works Cited}

Aiyetoro, Adjoa. 2001. "Formulating Reparations Litigation Through the Eyes of the Movement.” NYU Annual Survey of American Law 58: 457-74.

Alexander, Michelle. 2012. The New Jim Crow. New York: The New Press.

Amighetti, Sara, and Alasia Nuti. 2015. "Towards a Shared Redress: Achieving Historical Justice Through Democratic Deliberation.” Journal of Political Philosophy 23 (4): 385405.

Austin, James, and Lauren-Brooke Eisen. 2016. "How Many Americans Are Unnecessarily Incarcerated?” New York: Brennan Center for Justice. https://www.brennancenter.org/sites/default/files/publications/Unnecessarily_Incarcerate d_0.pdf.

Beals, Melba Pattillo. 2007. Warriors Don’t Cry. New York: Simon Pulse.

Bell Jr., Derrick A. 1979. "Bakke, Minority Admissions, and the Usual Price of Racial Remedies.” California Law Review 67 (1): 3-19.

Berry, Mary Frances. 2005. My Face Is Black Is True: Callie House and the Struggle for ExSlave Reparations. New York: Alfred A. Knopf.

— . 2014. "We Need a 'Reparations Superfund.” New York Times, June 9. http://www.nytimes.com/roomfordebate/2014/06/08/are-reparations-due-to-africanamericans/we-need-a-reparations-superfund. 
Bittker, Boris. 1972. The Case for Black Reparations. Boston, MA: Beacon Press.

Bouie, Jamelle. 2014. “Reparations Are Owed: Here Are a Few Ways to Pay the Bill.” Slate, May 22.

http://www.slate.com/articles/news_and_politics/politics/2014/05/reparations_should_be _paid_to_black_americans_here_is_how_america_should.html.

Brooks, Roy L. 1996. Integration or Separation? Cambridge, MA: Harvard University Press.

Cato v. United States, 70 F.3d 1103 (9 ${ }^{\text {th }}$ Cir. 1995).

Chettiar, Inimai, and Michael Waldman, eds. 2015. Solutions: American Leaders Speak Out On Criminal Justice. New York: Brennan Center for Justice.

Clotfelter, Charles T. 2004. After "Brown": The Rise and Retreat of School Desegregation. Princeton: Princeton University Press.

Coates, Ta-Nehisi. 2014. “The Case for Reparations.” Atlantic, June. http://www.theatlantic.com/magazine/archive/2014/06/the-case-for-reparations/361631/.

Crocker, David. 1998. "Transitional Justice and International Civil Society.” Constellations 5 (4): 492-517.

Darby, Derrick. 2010. “Reparations and Racial Inequality.” Philosophy Compass 5 (1): 55-66.

Davis, Angela. 2016. Freedom Is a Constant Struggle. Chicago: Haymarket Books.

Davis, Fania. 2016. "This Country Needs a Truth and Reconciliation Process on Violence Against African Americans-Right Now.” YES! Magazine, July 8.

http://www.yesmagazine.org/peace-justice/this-country-needs-a-truth-and-reconciliationprocess-on-violence-against-african-americans.

Dawson, Michael, and Rovana Popoff. 2004. "Reparations: Justice and Greed in Black and White.” Du Bois Review 1: 47-91.

Elster, Jon. 2004. Closing the Books: Transitional Justice in Historical Perspective. Cambridge: Cambridge University Press.

Eltagouri, Marwa. 2017. “Chicago’s New Center for Police-Torture Victims Is First of Its Kind in U.S.” Chicago Tribune, May 27. http://www.chicagotribune.com/news/local/breaking/ct-burge-torture-justice-center-met20170526-story.html.

Fiss, Owen M. 1997. “Affirmative Action as a Strategy of Justice.” Philosophy \& Public Policy 17: 37-38.

Garland, David, ed. 2001. Mass Imprisonment. London: SAGE Publications.

Gidursky, Ryan. 2016. "Millennials Open to the Idea of Slavery Reparations: Thank Academia?” Red Alert Politics. May 12. http://redalertpolitics.com/2016/05/12/millennials-open-ideaslavery-reparations-thank-academia/.

Hamilton, Darrick, and William Darity Jr. 2010. "Can 'Baby Bonds’ Eliminate the Racial Wealth Gap in Putative Post-Racial America?” Review of Black Political Economy 37: 207-16.

Harris, Fredrick. 2015. “The Next Civil Rights Movement?” Dissent. https://www.dissentmagazine.org/article/black-lives-matter-new-civil-rights-movementfredrick-harris.

Heaton, Paul, Sandra Mayson, and Megan Stevenson. 2017. "The Downstream Consequences of Misdemeanor Pretrial Detention.” Stanford Law Review 69 (3): 711-94.

Henry, Charles P. 2003. “The Politics of Racial Reparations.” Journal of Black Studies 34 (2): 131-52. 
Holland, Jess. 2016. “Older Whites Overwhelmingly against Reparations for Slavery, but Millennials Are Not as Opposed.” US News \& World Report. May 11.

https:/www.usnews.com/news/politics/articles/2016-05-11/poll-millennials-more-opento-idea-of-slavery-reparations.

Howard-Hassmann, Rhoda. 2004. "Getting to Reparations: Japanese Americans and African Americans.” Social Forces 83: 823-40.

Ifill, Sherrilyn. 2003. "Creating a Truth and Reconciliation Commission for Lynching.” Law \& Inequality 21: 263-311.

In re African American Slave Descendants, 471 F.3d 754 ( $7^{\text {th }}$ Cir. 2006).

Johnson v. McAdoo, 244 U.S. 643 (1917).

King, Desmond. 2014. “America’s Civil Rights State: Amelioration, Stagnation or Failure?” In Developments in American Politics, ed. Gillian Peele, Christopher J. Bailey, Bruce Caine, and B. Guy Peters, 7th ed., 263-83. London: Palgrave Macmillan.

King, Desmond, and Rogers M. Smith. 2011. Still a House Divided. Princeton University Press. Lee, Hedwig, et al. 2015. "Racial Inequalities In Connectedness To Imprisoned Individuals In The United States.” Du Bois Review 12 (2): 269-82.

Marable, Manning. 2004. “In Defense of Black Reparations.” Freedom and Justice Crier.

Mazumder, Bhashkar. 2014. "Black-White Differences in Intergenerational Economic Mobility in the United States.” Chicago: Chicago Federal Reserve Board. https://www.chicagofed.org/ /media/publications/economic-perspectives/2014/1q2014part1-mazumder-pdf.pdf.

McCoy, Brian. 2014. "Renewed Call for Reparations.” NAACP.org. May 30. http://www.naacp.org/blog/entry/renewed-call-for-reparations.

Munford, C. J. 2007. "Reparations: Strategic Considerations for Black Americans.” In Redress for Historical Injustices in the United States, ed. Michael T. Martin and Marilyn Yaquinto, 447-51. Durham: Duke University Press.

Ogletree Jr., Charles. 2004. “Tulsa Reparations: The Survivors’ Story.” Boston College Third World Law Journal 24: 13-30.

Page, Jennifer M. 2015. "Reparations and State Accountability.” Ph.D. Dissertation, Cambridge, MA: Harvard University.

Pettit, Philip. 2007. “Responsibility Incorporated.” Ethics 117 (2): 171-201.

"Platform.” 2017. The Movement for Black Lives. https://policy.m4bl.org/platform/.

Porter, Nicole. 2016. "Unfinished Project of Civil Rights in the Era of Mass Incarceration and the Movement for Black Lives.” Wake Forest Journal of Law and Policy 6 (1): 1-34.

powell, john a. 2007. "Structural Racism and Spatial Jim Crow." In The Black Metropolis in the 21st Century: Race, Power, and Politics of Place, ed. Robert D. Bullard, 41-65. Lanham, MD: Rowman \& Littlefield.

"Report of the Working Group of Experts on People of African Descent on Its Mission to the United States of America.” 2016. United Nations Human Rights Council. https://documents-dds-ny.un.org/doc/UNDOC/GEN/G16/183/30/PDF/G1618330.pdf.

Shapiro, Thomas, Tatjana Meschede, and Sam Osoro. 2013. "The Roots of the Widening Racial Wealth Gap.” Institute on Assets and Social Policy Research and Policy Brief. http://www.naacpldf.org/files/case_issue/Shapiro\%20racialwealthgapbrief.pdf.

Skolnick, Jerome, and James Fyfe. 1994. Above the Law. New York: Free Press.

Skrentny, John David. 1996. The Ironies of Affirmative Action. Chicago: University of Chicago Press. 
Subramanian, Ram, et al. 2015. “Incarceration’s Front Door.” Vera Institute of Justice. https://jpo.wrlc.org/bitstream/handle/11204/3988/Vera\%20Report\%20\%20Misuse\%20of\%20Jails\%20-\%202015.pdf.

Taylor, G. Flint. 2015. “Reparations Won.” Police Misconduct and Civil Rights Law Report 11: $1-10$.

Teitel, Ruti. 2000. Transitional Justice. Oxford: Oxford University Press. . 2015. Globalizing Transitional Justice. Oxford: Oxford University Press.

“Transitional Justice Initiative: Truth Commissions.” 2016. Washington D.C.: United States Department of State. https://www.state.gov/documents/organization/257772.pdf.

Travis, Jeremy, Bruce Western, and Steve Redburn, eds. 2014. The Growth of Incarceration in the United States. Washington D.C.: National Academies Press.

Unger, Roberto Mangabeira. 1996. What Should Legal Analysis Become? London: Verso.

Valls, Andrew. 2003. "Racial Justice as Transitional Justice.” Polity 36 (1): 53-71.

Wacquant, Loic. 2001. "Deadly Symbiosis: When Ghetto and Prison Meet and Mesh.” Punishment \& Society 3 (1): 95-133.

Waldron, Jeremy. 2006. “The Core of the Case against Judicial Review.” Yale Law Journal, 1346-1406.

Weaver, Vesla M. 2007. "Frontlash: Race and the Development of Punitive Crime Policy.” Studies in American Political Development 21 (2): 230-65.

Westley, Robert. 1998. "Many Billions Gone: Is It Time to Reconsider the Case for Black Reparations.” Boston College Third World Law Journal 19: 429-76.

Williams, Melissa, and Rosemary Nagy. 2012. "Introduction.” Nomos LI: Transitional Justice: $1-30$. 